\title{
Predation by copepods upon natural populations of Phaeocystis pouchetii as a function of the physiological state of the prey
}

\author{
Kenneth W. Estep ${ }^{1}$, Jens Ch. Nejstgaard ${ }^{2}$, Hein Rune Skjoldal ${ }^{1}$, Francisco Rey ${ }^{1}$ \\ ${ }^{1}$ Institute of Marine Research, Postbox 1870, Nordnes, N-5024 Bergen, Norway \\ ${ }^{2}$ University of Bergen, Department of Marine Biology, N-5065 Blomsterdalen, Norway
}

\begin{abstract}
Conflicting data have been previously presented on the ability of copepods to prey upon the prymnesiophyte Phaeocystis pouchetii. While some have suggested that gelatinous colonies of this species contain biochemical substances that prevent their consumption, others have shown that both single cells and colonies of $P$. pouchetii can serve as an excellent food source. The present study presents data from feeding experiments using 4 species of copepods and natural samples of phytoplankton prey from a south-north transect during May 1989 in the Barents Sea. Natural phytoplankton contained $P$. pouchetii colonies in association with varying amounts of diatoms. Along the transect these colonies varied from highly fluorescent and healthy in the north, to weakly fluorescent in the south. Results of experiments using both image analysis and radiotracer techniques indicate that diatoms were actively preyed upon in all experiments, with long-chain-forming species as the preferred food. Predation upon $P$. pouchetii colonies was dependent upon the physiological condition of the colonies. Healthy colonies were not consumed, while susceptible colonies were consumed at rates 2 to 10 times those for chain-forming diatoms. The selective predation described here has important implications for species composition in Arctic waters.
\end{abstract}

\section{INTRODUCTION}

Is Phaeocystis pouchetii (Hariot) grazed by herbivorous zooplankton? $P$. pouchetii blooms have been reported to have harmful effects on migration of fish populations (Savage 1930) and on fish catches (Bradstock \& MacKenzie 1981, Chang 1984). Sieburth (1958, $1960,1965)$ documented the sterility of penguin guts in populations feeding upon euphausiids in Antarctic $P$. pouchetii blooms. Sterility imparted to the guts of these animals was demonstrated to be a function of acrylic acid produced by $P$. pouchetii colonies (Sieburth 1961). An inhibitory effect of $P$. pouchetii colonies upon zooplankton predation has also been suggested (Martens 1980, 1981, Daro 1985, Schnack et al. 1985, Claustre et al. 1990). However, the inhibitory effect of $P$. pouchetii has recently been called into question by field and laboratory experiments showing active predation by copepods upon colonies and single cells of $P$. pouchetii (Eilertsen et al. 1989, Tande \& Båmstedt 1987). Huntley et al. (1987) comment that 'It is difficult to say exactly how the legend of Phaeocystis unpalatability to zooplankton began' [our emphasis]. Although Verity \&
Smayda (1989) have reported a lack of $P$. pouchetii ingestion by Acartia spp., they attributed this phenomenon to the size of the colonies, rather than to chemical undesirability.

Phaeocystis pouchetii is a member of the Prymnesiophyceae, a group known for the production of toxic or harmful compounds (Shilo 1967. Carmichael 1986, Estep \& MacIntyre 1989a). P. pouchetii alternates between a gelatinous colony with a large number of nonmotile, embedded cells, and a motile swarmer stage with 2 flagella and a haptonema (Chang 1984). A non-motile benthic stage may also be present (Kayser 1970). It is an important species in Antarctic and Arctic ecosystems, as well as in some temperate and boreal waters (Burkholder \& Sieburth 1961, Lancelot et al. 1987). In the Barents Sea the colonial form of this species typically dominates the spring bloom, along with diatoms. The relative abundance of diatoms and $P$. pouchetii appears to vary depending upon the stock of zooplankton, possibly as a result of discrimination against $P$. pouchetii by copepods, allowing this alga to dominate in the presence of large zooplankton stocks (Skjoldal \& Rey 1989). 
The production of toxic chemical compounds by prymnesiophytes (e.g. Prymnesium and Chrysochromulina) is highly dependent on the physiological state of the organism (Shilo 1967), and possibly on the presence or absence of particular co-occurring species in the population (Estep \& MacIntyre 1989a). If there is any truth to the unpalatability of Phaeocystis pouchetii, we would expect the same relationship with physiological condition to be important. We therefore set out to examine copepod predation upon $P$. pouchetii colonies in different physiological states to determine if feeding behaviour was variable or constant. The present paper examines 5 stations where $P$. pouchetii occurred in different physiological conditions and with variable amounts of co-occurring diatoms. Using a combination of image analysis and radiotracer experiments, we demonstrate that, while predation upon diatoms was constant for all stations, predation upon $P$. pouchetii was a function of the physiological state of the colonies.

\section{MATERIALS AND METHODS}

Sampling and experimental setup. Sample collection, experimental work and data recording were conducted between 13 and 22 May 1989, during a cruise in the Barents Sea onboard the RV 'G.O. Sars'. We chose 5

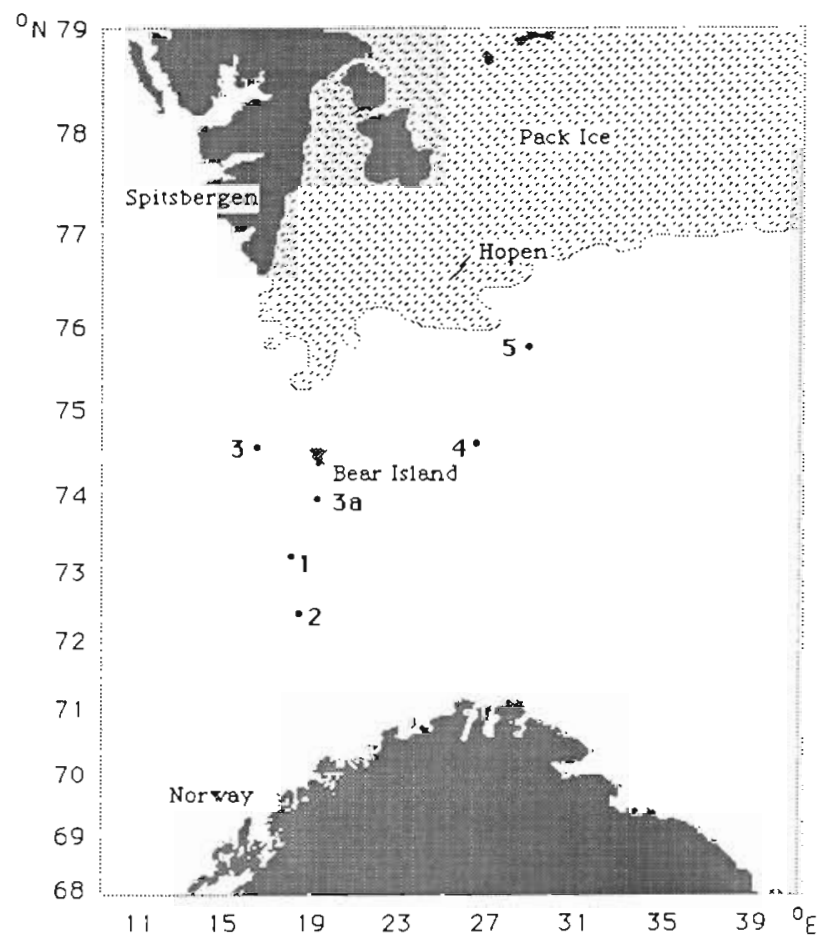

Fig. 1. Sampling stations where natural populations of algae and zooplankton were obtained for predation experiments. In Expt 3, algae were collected from Stn 3a but incubated with zooplankton taken at $\operatorname{Stn} 3$ stations for predation experiments (Fig. 1). Stns 1 and 2 were located in Atlantic water in the western Barents Sea. Stn 3 was located in the polar front region west of Bear Island. Stns 4 and 5 were located in the Hopen Depth in Atlantic water east of Bear Island and in meltwater closer to the ice edge, respectively. Stns 1 to 5 correspond to RV 'G.O. Sars' Stns 578, 586, 595, 604 and 612, respectively.

Stations were selected on the basis of the physiological condition of Phaeocystis pouchetii colonies. Physiological condition was determined by the fluorescence of individual cells within the colonies. Phytoplankton lose their autofluorescence when in poor condition; reductions of $30 \%$ immediately upon death and $75 \% 24 \mathrm{~h}$ after death have been reported (Tsuji \& Yanagita 1981). Healthy $P$. pouchetii populations normally form lobed colonies with individual cells showing medium-bright, red-orange autofluorescence, while cells from unhealthy colonies lose fluorescence and individual colonies become depleted of cells, the latter due either to cell death or to transformation to the motile stage (Verity et al. 1988).

Copepods for predation experiments were collected with 50,100 or $150 \mathrm{~m}$-to-surface vertical net hauls, using a WP2 net (mesh size $200 \mu \mathrm{m}, 1 \mathrm{~m}$ opening diameter) fitted with a PVC plastic bag in a $14 \mathrm{l}$, nonfiltering, black cod-end. Temperature differences from bottom to top of the net hauls were always less than $2{ }^{\circ} \mathrm{C}$. To minimize disturbance to the animals as a result of collection and handling, the net was retrieved at $0.2 \mathrm{~m} \mathrm{~s}^{-1}$. Upon arrival at the surface, the plastic bag containing the sample was immediately removed from the cod-end without rinsing. This treatment avoided inclusion of animals attached to the net that may have been damaged during the haul. Actively swimming and feeding copepods, as defined by Mackas \& Burns (1986), were gently siphoned from the sample, and replicate, monospecific groups of 3 to 25 adult females and Stage CV copepodites were immediately pipetted into beakers with $40 \mathrm{ml}$ of $0.47 \mathrm{um}$ Nuclepore-filtered seawater at in situ temperatures. Individuals were pipetted under a Wild M5A dissecting microscope using dim light to minimize disturbance of the animals.

Natural populations of phytoplankton prey were collected from the same sites at a depth of $20 \mathrm{~m}$, approximately equal to the weak chlorophyll maximum, using 301 Niskin bottles. Contaminating zooplankton were removed from the samples, and the natural, unconcentrated algal assemblages were used as prey for the copepods. In Expts 1, 2, 4 and 5, algae were inoculated with copepods within $1 \mathrm{~h}$. In Expt 3, the algal sample (collected at Stn 3a; Fig. 1) was incubated on deck for $6 \mathrm{~d}$ to induce senescence, by depleting residual nitrate from the culture.

Microscopic image analysis experiments. Predation 
Table 1. Number and size of copepods contained in experimental flasks for image-analysis experiments

\begin{tabular}{|c|c|c|c|c|}
\hline Expt & No. of flasks & Species & No. of ind. & $\begin{array}{c}\text { Mean cephlothorax } \\
\text { length }(\mathrm{mm})\end{array}$ \\
\hline 1 & 3 & Calanus finmarchicus & 23 & 2.75 \\
\hline 2 & 3 & Calanus finmarchucus & $16-18$ & 2.77 \\
\hline 2 & 1 & Calanus hyperboreus & 3 & 6.56 \\
\hline 2 & 3 & Metridia longa & $18-20$ & 2.66 \\
\hline 3 & 3 & Calanus finmarchicus & $13-15$ & 2.90 \\
\hline 3 & 3 & Calanus hyperboreus & 5 & 6.78 \\
\hline 4 & 3 & Calanus finmarchicus & $17-19$ & 3.18 \\
\hline 5 & 3 & Calanus finmarchicus & $16-21$ & 3.03 \\
\hline 5 & 2 & Calanus hyperboreus & $4-5$ & 6.12 \\
\hline 5 & 1 & Calanus glacialis & 14 & 3.99 \\
\hline
\end{tabular}

experiments were conducted in $800 \mathrm{ml}$ polyethylene tissue-culture flasks, each with in situ concentrations of phytoplankton and, except in the controls, 3 to 25 individuals from a single copepod species (Table 1 ). The size of the culture flask was chosen as a compromise to reduce edge effects (Mullin 1963, Tackx \& Polk 1986, O'Brien 1988) while retaining a sufficient copepod concentration to give measurable predation. Experiments were begun immediately after sufficient copepods had been sorted (less than $1.5 \mathrm{~h}$ after sample collection) to minimize handling and starvation effects (Mullin 1963, McAllister 1970, Mackas \& Burns 1986).

Natural populations of algae from each station were thoroughly mixed and $760 \mathrm{ml}$ portions were added to replicate bottles for each species of copepod. Experiments were begun by carefully pouring each $40 \mathrm{ml}$ portion containing the copepods into experimental flasks, and adding a corresponding amount of filtered water to the control flasks. Experimental and control flasks were incubated in a 180 l PVC tank with running seawater at in situ temperature. Flasks were free-floating and exposed to subdued light throughout the experiment. The flowthrough system created gentle, irregular agitation that kept the phytoplankton cells in suspension while minimizing breakage.

At the end of the experiments, the number of copepods was checked for each flask, and each copepod was measured using an eyepiece micrometer on a Wild M5A dissecting microscope. No copepod mortality occurred during the course of the experiments.

Samples for phytoplankton analysis $(40 \mathrm{ml})$ were taken from the experimental flasks at the start of each experiment and at discrete time intervals ( 1 to $22 \mathrm{~h}$ ) thereafter, and preserved to an end concentration of $0.5 \%$ with $5 \%$ gluteraldehyde-formalin. Of each sample, 5 to $10 \mathrm{ml}$ was filtered onto $0.6 \mu \mathrm{m}$, Irgalan-black- stained filters and stained with $75 \mu \mathrm{g} \mathrm{m} \mathrm{m}^{-1}$ Primulin (in $0.1 \mathrm{M}$ Trizma $\mathrm{HCl}, \mathrm{pH}$ to 4.0 ) for $30 \mathrm{~min}$. Stained filters were examined with UV (BP 365, FT 395, LP 397) and blue light (450 to 490, FT 510, LP 520) using a Zeiss Axioplan epifluorescence microscope (Carl Zeiss, F.R. Germany). When examined with the UV filter, the staining procedure used here imparts a blue colour to protistan protoplasm and a dull-fluorescent-brown colour to the mucus matrix surrounding phaeocystis pouchetii colonies. The characteristic fluorescence in the latter allows the colonies to be identified and sized, even when they are devoid of cells. When examined with the blue filter, photosynthetic nanoplankton and cyanobacteria autofluoresce red and orange, respectively.

For both the experimental and control flasks, the number and size of Phaeocystis pouchetii colonies, the number of cells per $P$. pouchetii colony, the number and length of diatom chains, the number of cyanobacteria and the number of photosynthetic (Pnano) and heterotrophic nanoplankton (Hnano) were determined semi-automatically using the Zeus (A/S Pixelwerks, Bergen) Image Analysis System (ZIA) (Estep \& MacIntyre 1989b). Diatom chain length is expressed as total length of curved chains as if straightened. Analysis of all data by ZIA was completed onboard within $24 \mathrm{~h}$ of sample collection. Diatom community structure at each station was determined ashore on samples preserved with Lugols lodine, settled in Utermöhl chambers, and examined with an inverted microscope (Olympus Optical, Tokyo).

Data from ZIA is presented as concentrations of each morphological type or species measured in the experiments. Where predation occurred, data were fitted with exponential lines. The initial point for each graph represents the algal concentration in the large algal flask that served as the innoculum for the predation flasks. In 
some flasks a small number of points were determined and we are not sure that the actual feeding response was exponential; however exponential lines were fitted for consistency.

Behavioural observations. Feeding behaviour of Calanus finmarchicus was examined in Expts 4 and 5 using a Wild M5A dissecting microscope at the end of the ZIA experiments, at a time when Phaeocystis pouchetii colonies were still abundant, noting the response of the animals during encounter and subsequent handling of $P$. pouchetii colonies.

ZIA predation rates. Clearance and ingestion rates for the ZIA experiments were calculated according to the equations of Frost (1972). Clearance rates are expressed as $\mathrm{ml}$ copepod ${ }^{-1} \mathrm{~h}^{-1}$. Ingestion rates are expressed as cells copepod ${ }^{-1} \mathrm{~h}^{-1}$ for Phaeocystis pouchetii cells and single diatoms, as colonies or chains copepod $^{-1} \mathrm{~h}^{-1}$ for $P$, pouchetii colonies and diatom chains, and $\mathrm{cm}$ copepod ${ }^{-1} \mathrm{~h}^{-1}$ for diatom chain length.

Radiotracer experiments. Radiotracer experiments were conducted at Stns 2 and 5. Samples of algal prey for radiotracer experiments were collected as described for the image-analysis experiments above. The phytoplankton were labeled with $160 \mu \mathrm{Ci}$ of $\mathrm{Na}_{2} \mathrm{H}^{14} \mathrm{CO}_{3}$ per $4 \mathrm{l}$ of water, and incubated in subdued light on deck for $24 \mathrm{~h}$. Copepods for radiotracer experiments were gently siphoned from the net-haul samples and concentrated on a $500 \mu \mathrm{m}$ mesh, submersed at in situ temperature in $0.47 \mu \mathrm{m}$ filtered seawater, yielding zooplankton in the size range of Calanus finmarchicus copepodite Stage III and larger. Zooplankton were incubated with radioactive phytoplankton under conditions similar to those for the ZIA experiments. Copepods were sampled at discrete time intervals $(20$ min to $1 \mathrm{~h}$ ), anaesthetized in MS222, sorted into replicate groups of 1 to 40 individuals of the same species and stage, and placed in scintillation vials. Copepods previously anaesthetized with MS222 and incubated in replicate radioactive water were used as controls.

Immediately prior to the start of the experiments, duplicate aliquots of the radioactive phytoplankton sample were filtered onto $0.45 \mu \mathrm{m}$ membrane filters. Filters were then exposed to $\mathrm{HCl}$ fumes for 15 min, immersed in $7 \mathrm{ml}$ of Optifluor (Packard) scintillation cocktail, and counted using the channel-ratio method for calculating counting efficiency. At the end of each experiment the copepods in the experimental vials were solubilized in $1 \mathrm{ml}$ of Soluene-350 tissue solubilizer (Packard) for $12 \mathrm{~h}$ at $50^{\circ} \mathrm{C}$. Thereafter $10 \mathrm{ml}$ Hionic-Fluor (Packard) scintillation cocktail was added to the vials and their radioactivity measured in a Packard Tri-Carb scintillation counter. Counting efficiency was calculated by the channel-ratio method using a quenching curve obtained with varying amounts of fresh zooplankton with known amounts of ${ }^{14} \mathrm{C}$. Clear- ance rates were calculated using the equations of Omori \& Ikeda (1984).

\section{RESULTS}

\section{Station description}

The spring phytoplankton bloom in the Barents Sea is strongly dependent upon the physical conditions, developing slowly in response to thermocline formation in Atlantic water, but more rapidly in response to ice melt in ice-covered waters (Rey et al. 1987, Skjoldal et al. 1987. Sakshaug \& Skjoldal 1989). The stations selected for the experiments (Fig. 1) were located in different water masses and had spring phytoplankton blooms developing in different stages. Stns 1 and 2 had fairly homogeneous water columns with very weak pycnoclines at 70 to $80 \mathrm{~m}$. The temperature of the upper layer was about $5.5^{\circ} \mathrm{C}$. The spring phytoplankton growth had depleted about half the winter content of nutrients and the chlorophyll a concentration was 2 to $4 \mu \mathrm{g}^{-1}$. Stn 3 had similar conditions, except that temperature $\left(0^{\circ} \mathrm{C}\right)$ and salinity $(34.7 \%$ ) were lower. Stn 4 had a shallower and somewhat stronger pycnocline located at $40 \mathrm{~m}$. Stn 5 was located in the meltwater region and had a fairly strong pycnocline at about $15 \mathrm{~m}$. Nitrate was depleted from the upper layer at both stations and the chlorophyll a content was about $2 \mu \mathrm{g}^{-1}$. In contrast to nitrate, an abundant supply of silicate still remained in the water $(4.0$ to $4.5 \mu \mathrm{M})$.

Expts 1 and 2 were conducted with algal prey dominated by a bloom of Phaeocystis pouchetii apparently in poor condition. $P$. pouchetii populations from Stns 1 and 2 exhibited round, non-lobed colonies, with individual cells that showed little or no autofluorescence. Small numbers of the diatom Nitzschia delicatissima were also present. Stns 3 and 4 were intermediate: $P$. pouchetii were in apparently good shape and shared dominance with several species of chain-forming diatoms and a single-celled diatom. Stn 5 was closest to the ice edge and was dominated by a recent $P$. pouchetii bloom, with a much smaller number of diatom cells. The number of $P$. pouchetii colonies per litre was fairly constant for all stations (8000 to 16000$)$ and did not show a clear north-south trend (Table 2). Total zooplankton per litre, by contrast, showed a clear north-south trend with the highest value at Stn 1 (1610 ind $\mathrm{m}^{-3}$ ) and the lowest value at $\operatorname{Stn} 5$ (131 ind. $\mathrm{m}^{-3}$ ).

\section{Zeus image analysis}

Phaeocystis pouchetii from Expt 1 showed a rapid reduction in both the number of colonies and the mean 
Table 2. Description of in situ populations at the experimental sites, listed in order of relative abundance

\begin{tabular}{|c|c|c|}
\hline Expt & Dominant algal species & $\begin{array}{l}\text { Dominant zooplankton } \\
\text { species }^{b^{2}}\end{array}$ \\
\hline 1 & $\begin{array}{l}\text { Phaeocystis pouchetii (15) } \\
\text { Nitzschia delicatissima }\end{array}$ & $\begin{array}{l}\text { Calanus spp. }{ }^{\circ} \mathrm{I}-\mathrm{V}(1610) \\
\text { Oithona } \\
\text { C. finmarchicus VI }\end{array}$ \\
\hline 2 & $\begin{array}{l}\text { Phaeocystis pouchetii (12) } \\
\text { Nitzschia delicatissima }\end{array}$ & $\begin{array}{l}\text { Calanus spp. IV (975) } \\
\text { Oithona } \\
\text { Oncaea } \\
\text { C. tinmarchicus VI }\end{array}$ \\
\hline $3^{d}$ & $\begin{array}{l}\text { Phaeocystis pouchetii }\{8\} \\
\text { Thalassiosira antarctica }\end{array}$ & $\begin{array}{l}\text { Calanus sp. I-V (885) } \\
\text { Oithona } \\
\text { Pseudocalanus } \\
\text { Oncaed } \\
\text { C. finmarchicus VI }\end{array}$ \\
\hline 4 & $\begin{array}{l}\text { Phaeocystis pouchetii }(11) \\
\text { Thalassiosira antarctica } \\
\text { Nitzschia delicatissima } \\
\text { Thalassiosira nordenskioldii } \\
\text { Chaetoceros convolutus } \\
\text { C. debilis }\end{array}$ & $\begin{array}{l}\text { Calanus sp. I-V (209) } \\
\text { Oithona } \\
\text { C. finmarchicus VI }\end{array}$ \\
\hline 5 & $\begin{array}{l}\text { Phaeocystis poucheti (16) } \\
\text { Chaetoceros debilis } \\
\text { Nitzschia delicatissima } \\
\text { Chaetoceros convolutus } \\
\text { Thalassiosira antarctica }\end{array}$ & $\begin{array}{l}\text { Calanus sp. I-V (131) } \\
\text { Oithona } \\
\text { C. finmarchicus V1 }\end{array}$ \\
\hline \multicolumn{3}{|c|}{$\begin{array}{l}\text { a Phaeocystis pouchetii colonies per } \mathrm{ml} \text { are indicated in paren- } \\
\text { thesis (numbers of others species were not determined indi- } \\
\text { vidually) } \\
\text { b Total no. of ind. per } \mathrm{m}^{3} \text { (including all species) is indicated in } \\
\text { parenthesis } \\
\text { c Including Stage I to } V \text { of C. finmarchicus and C. glacialis } \\
\text { d Algae were collected at Stn } 3 a \text { and zooplankton at } S \operatorname{tn} 3\end{array}$} \\
\hline
\end{tabular}

colony area after $9 \mathrm{~h}$ in flasks with Calanus finmarchicus. P. pouchetil colonies were almost totally eliminated in the $18 \mathrm{~h}$ sample. Control flasks showed a much lower reduction in both number of colonies and mean colony area (Fig. 2A, C). The small reduction in the control flasks, indicating natural mortality in the absence of predators, is a further indication that $P$. pouchetii colonies at $\operatorname{Stn} 1$ were in poor condition. The number of empty colonies increased rapidly in the $9 \mathrm{~h}$ sample for the experimental flasks and decreased by the end of the experiment (Fig. 2B). By that time, nearly all remaining colonies were empty. The mean number of $P$. pouchetii cells per colony remained the same in the controls, while it dropped rapidly in the experimental flasks by $9 \mathrm{~h}$ (Fig. 2D).

Results for Calanus finmarchicus from Expt 2, where Phaeocystis pouchetii colonies were also in poor shape, are similar to those of Expt 1 (Figs. $3 \mathrm{~A}$ to D). Heterotrophic nanoplankton (Hnano) and phototrophic nanoplankton (Pnano) were also determined in Expt 2. Hnano counts showed an increase in control flasks and constant numbers in experimental flasks (Fig. 3E). Pnano, by contrast, showed a small increase and then a reduction to starting levels (Fig. 3F). In Expt 2 (C. hyperboreus and Metridia longa) the number of $P$. pouchetii colonies in both the experimental and control flasks was reduced and there was no clear grazing by either species (Fig, 4A, B).

In Expt 3 Phaeocystis pouchetii colonies appeared healthy and autofluorescent for the first $10 \mathrm{~h}$ after the start of this predation experiment. At the $22 \mathrm{~h}$ sample, $P$. pouchetii cells and colonies were similar in appear-

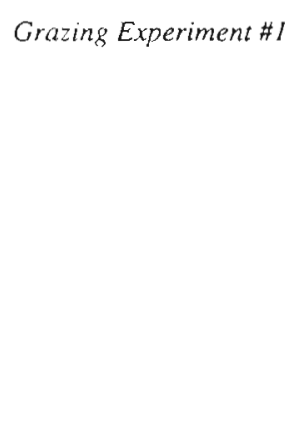

Fig. 2. ZIA Expt 1 Predation of Calanus finmarchicus on natural algal populations. Unhealthy Phaeocystis pouchetii colonies were efficiently consumed, as measured either by number of colonies $1^{-1}(A)$ or mean colony area (C). Number of empty colonies increased (B) and number of cells per colony decreased (D) as a result of predation. Symbols are: $(+)$ control; (o) C. finmarchicus
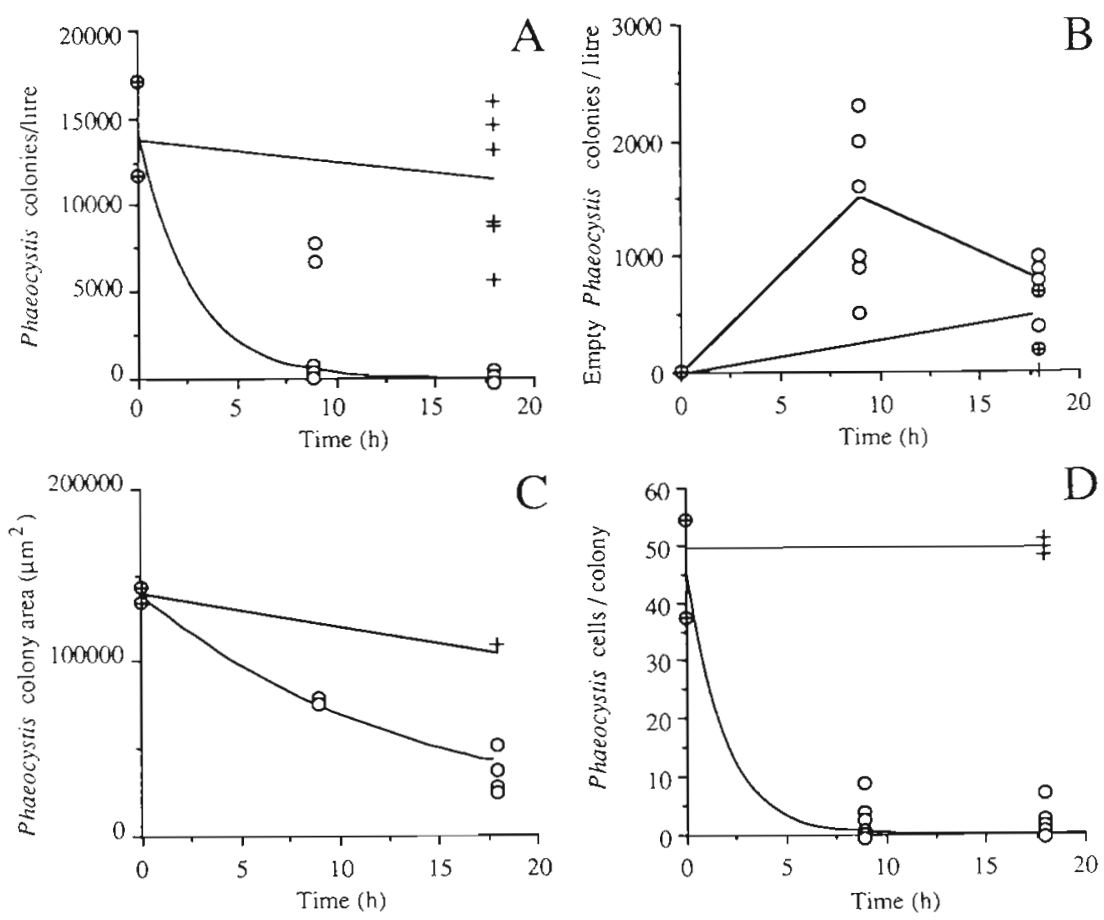
Grazing Experiment \#2
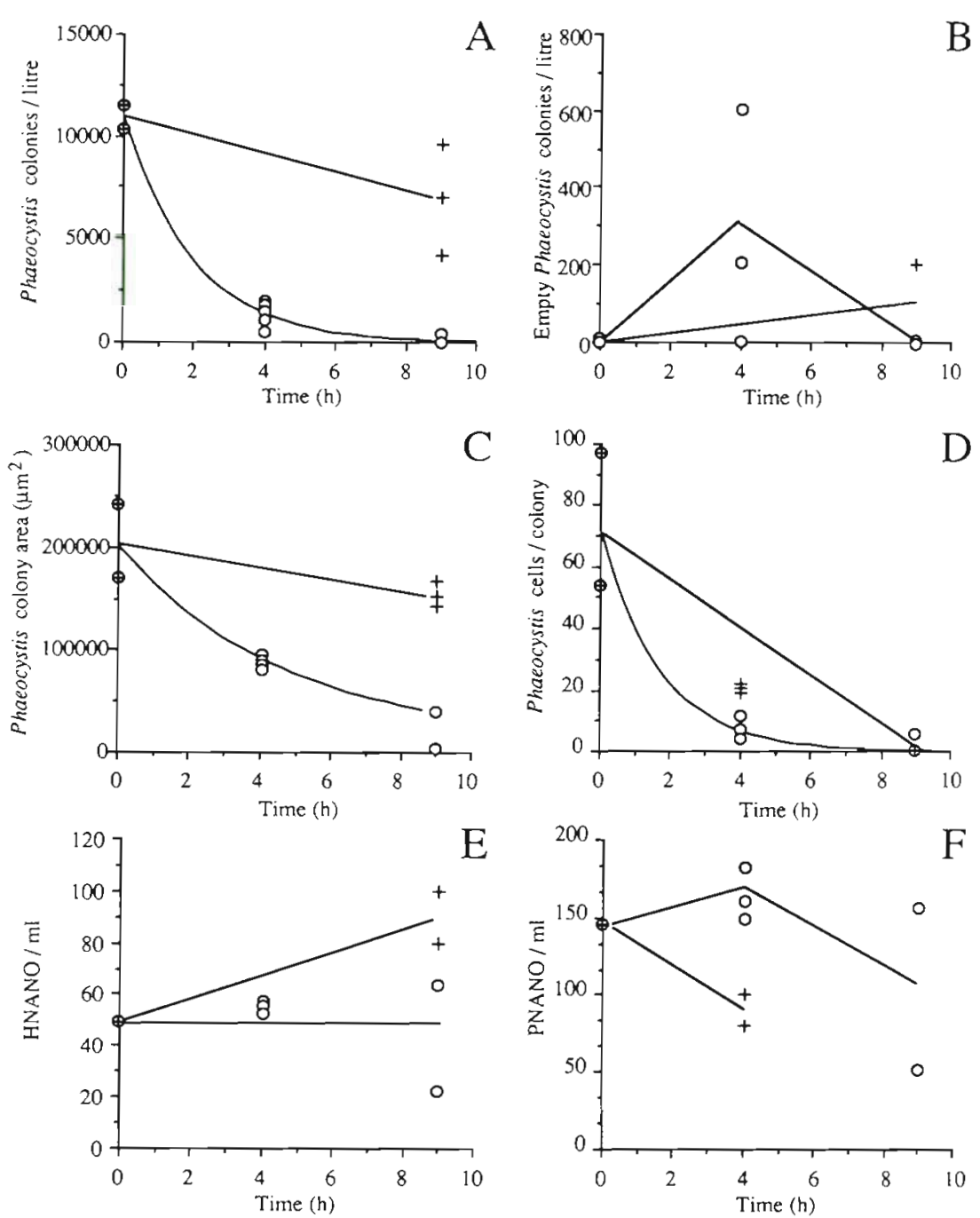

Fig. 3. ZIA Expt 2. Predation of Calanus finmarchicus on natural algal populations. Unhealthy Phaeocystis pouchetii colonies were efficiently consumed, as measured either by number of colonies $1^{-1}(A)$ or mean colony area (C). Number of empty colonies increased (B) and number of cells per colony decreased (D) as a result of predation. By contrast, Pnano and Hnano (no. photosynthetic and heterotrophic nanoplankton, respectively) did not change significantly during the experiment $(F, G)$, indicating that $P$. pouchetii cells from colonies were consumed, rather than liberated as a result of destruction of the colonies. Symbols as in Fig. 2

ance to those from Expts 1 and 2, indicating that the subdued light, container effects and the depletion of nitrate over a 6 to $7 \mathrm{~d}$ period had begun to have an adverse effect. Predation experiments with Calanus finmarchicus showed no reduction in the number of colonies for the first $10 \mathrm{~h}$ of the experiment, but at the 22 h sample, the number of $P$. pouchetii colonies was reduced as in Expts 1 and 2 (Fig. 5A, B).

In contrast to the delayed onset of predation upon Phaeocystis pouchetii, predation upon the dominant chain-forming diatoms was already apparent at the $5 \mathrm{~h}$ sample (Fig. 5C). Predation upon diatoms resulted in a rapid reduction in the mean diatom chain length (Fig. 5D). Behaviour of Calanus hyperboreus was similar for both $P$. pouchetii and chain-forming diatoms (Fig. 6A, B), but predation was less efficient on $P$. pouchetii at the $22 \mathrm{~h}$ sample. Selective predation upon the longest chains is clearly demonstrated by sorted- size-distribution histograms of diatom chain length (Fig, $7 \mathrm{~A}, \mathrm{~B}$ ). Controls remained the same, while chains in the experimental flasks showed a reduction in overall length, and a more rapid reduction in chain length for the longest chains (Fig. 7B).

Expt 4 was conducted in an area with a healthy Phaeocystis pouchetii bloom and co-occurring chainforming diatoms. Over a $13 \mathrm{~h}$ period, Calanus finmarchicus did not reduce the number of $P$. pouchetii colonies (Fig. 8A). Empty colonies per litre also remained constant with C. finmarchicus (Fig. 8B). Predation upon diatom chains by $C$. finmarchicus was similar to results for Expt 3, with a rapid reduction in the number of chains from the beginning of the experiment (Fig. 8C). Small centric diatoms (predominantly Thalassiosira sp.) also were reduced in the experimental flasks for $C$. finmarchicus, though to a lesser extent than found with the chain-forming species (Fig. 8D). The distributions 
Fig. 4. ZIA Expt 2. Predation of Calanus hyperboreus (A and B) and Metridia longa (C and D) on unhealthy Phaeocystis pouchetii colonies was not detected. Symbols are: $(+)$ control; (A) C. hyperboreus; $(\exists) M$. longa
Grazing Experiment \#2
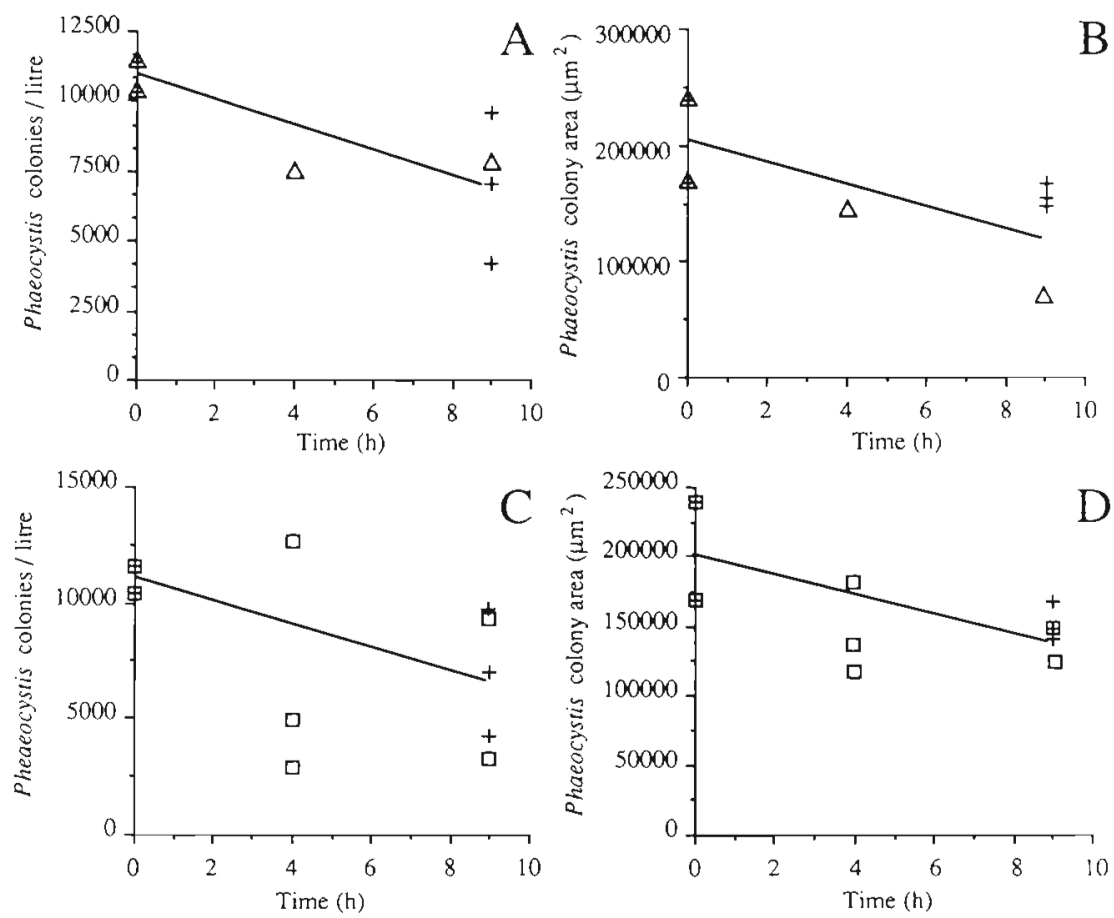

of Hnano and Pnano showed no differences between controls and C. finmarchicus (Fig. 8E, F).

Although Expt 4 ended at $13 \mathrm{~h}$, we continued to visually observe the experimental flasks every $4 \mathrm{~h}$ over the next $48 \mathrm{~h}$. Because Phaeocystis pouchetii colonies can be seen with the naked eye, this provided a rough estimate of predation upon $P$. pouchetii. Colony con- centration appeared constant until the $48 \mathrm{~h}$ sample, when nearly all of the $P$. pouchetii colonies appeared to have been swept clear from the flasks containing Calanus finmarchicus, while the control flasks remained unchanged.

Expt 5 was also conducted in an area with a healthy Phaeocystis pouchetii bloom, but with a lower concen-
Fig. 5. ZlA Expt 3. Predation of Calanus finmarchicus on natural populations of algae from a pre-enriched sample. Phaeocystis pouchetii was not consumed during the period 0 to $10.5 \mathrm{~h}$ when it appeared healthy (A and B), but was efficiently consumed by $24 \mathrm{~h}$, when it appeared unhealthy. By contrast, predation upon chain-forming diatoms (C) and single diatoms (D) began immediately. Symbols as in Fig. 2
Grazing Experiment \#3
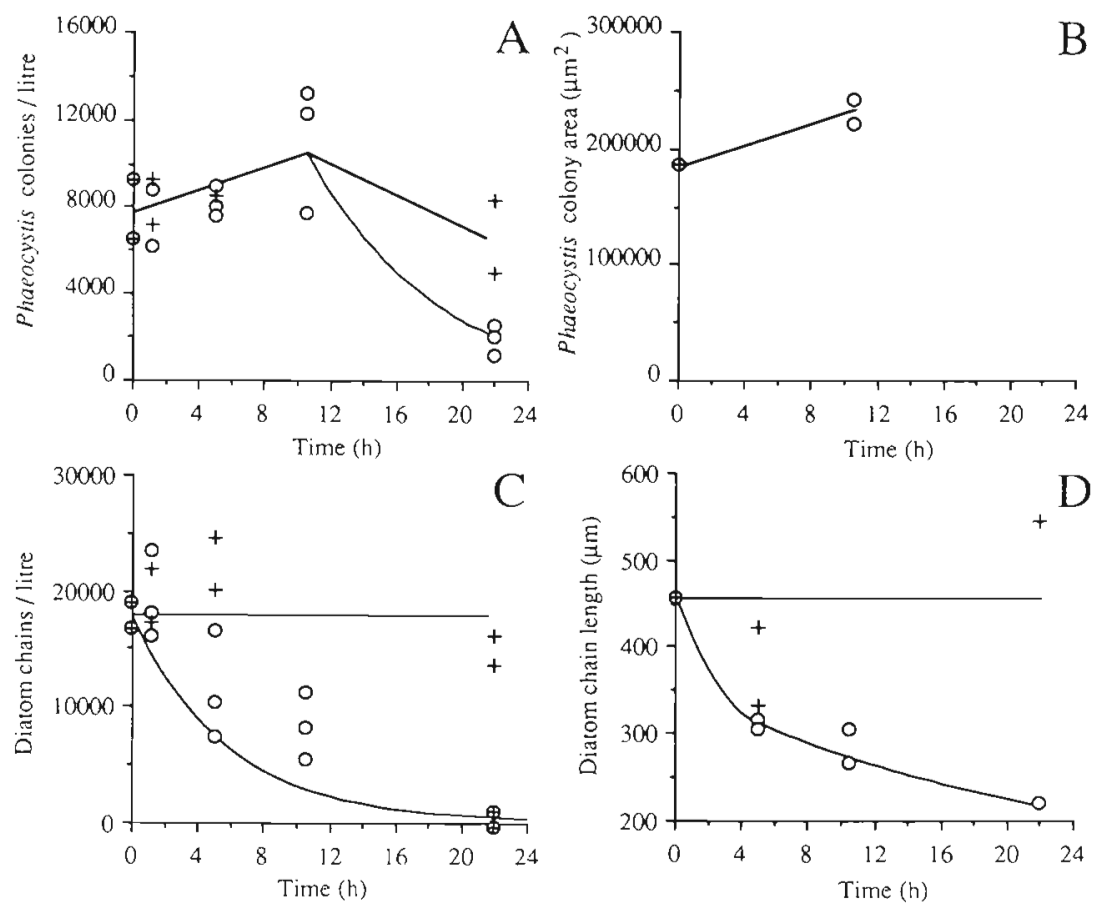

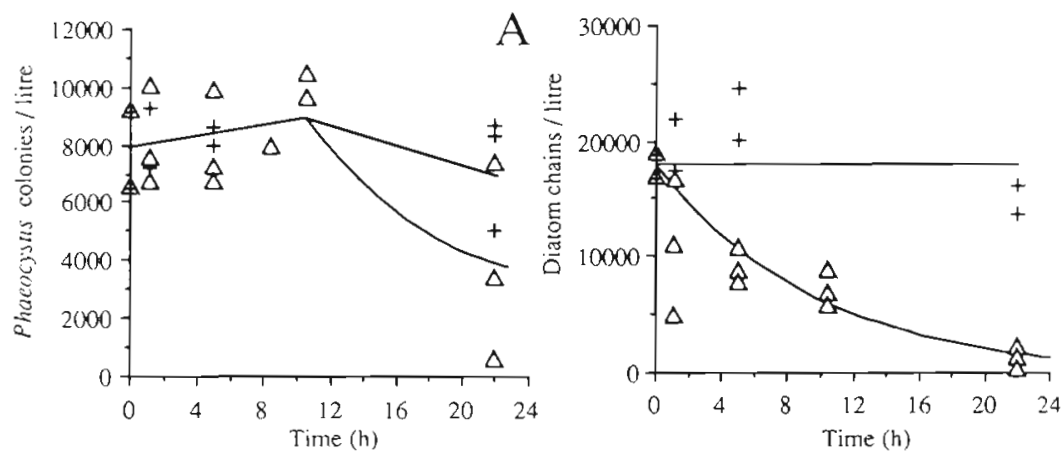

B

Fig. 6. ZIA Expt 3. Results of predation of Calanus hyperboreus on natural populations of algae from a pre-enriched sample. Phaeocystis pouchetii was not consumed during the period 0 to $10.5 \mathrm{~h}$ when it appeared healthy (A), but was consumed by $24 \mathrm{~h}$, when it appeared unhealthy. By contrast, predation upon chainforming diatoms (B) began immediately. Symbols are: (+) control; ( $\Delta$ ) C. hyperboreus tration (relative to Expt 4) of co-occurring chain-forming diatoms $\left(<200\right.$ diatom chains $\mathrm{l}^{-1}$ ). Results for Calanus finmarchicus, C. glacialis, and C. hyperboreus showed no predation upon $P$. pouchetii colonies over an 8 h period (Fig. $9 \mathrm{~A}$ to $\mathrm{C}$ ).

Coccoid cyanobacteria occurred at concentrations ca $10^{3} \mathrm{ml}^{-1}$ at Stns 1 to 3 , and did not change during the

\section{Grazing Experiment \#3}
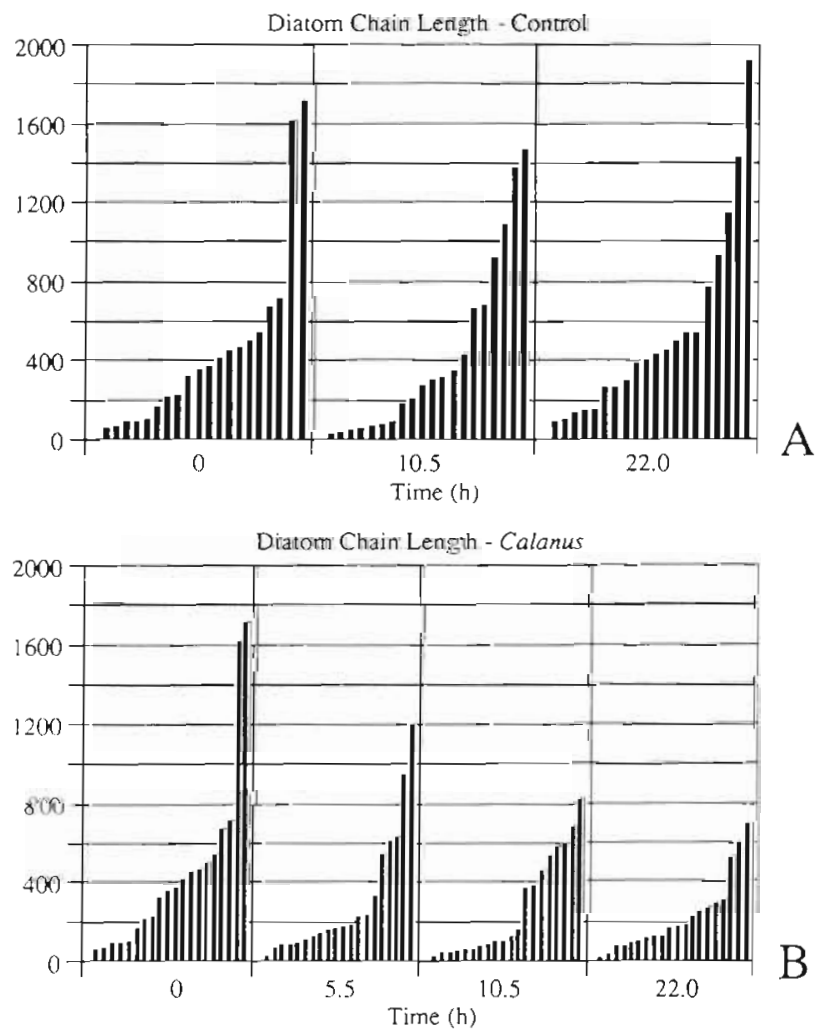

Fig. 7. ZIA Expt 3. Sorted size-distribution histograms of diatom chain length. Length of diatoms chains did not change significantly in controls (A). In predation experiments with Calanus finmarchicus, diatom chains were consumed, with a preference for the longest chains (B) course of the predation experiments. They were absent from water samples used in predation Expts 4 and 5.

\section{ZIA predation rates}

The results of the predation rate calculations for ZIA experiments are presented in Table 3. Clearance rates and ingestion rates for both centric diatoms (Expt 4) and number of diatom chains were within the range of previously published values for these prey groups (e.g. Frost 1972, Huntley et al. 1987). Predation rates upon Phaeocystis pouchetii in Expts 1 and 2, expressed either as number of colonies or number of cells within colonies, were much higher than the rates calculated for diatoms.

\section{Behavioural observations}

Behavioural observations on Calanus finmarchicus from Expts 4 and 5 were conducted between 12 and $24 \mathrm{~h}$, at a time when abundant Phaeocystis pouchetii colonies were present, but after chain-forming diatoms (in Expt 4) had been consumed. Swimming copepods encountered and brought whole $P$. pouchetii colonies into feeding position near the mouth at a rate of about 1 colony $\mathrm{min}^{-1}$. Once in position by the mouth, a delay of about 1 to 2 s occurred, perhaps related to tasting of the colony. After this delay, the intact colony was rejected and flipped by the appendages a distance of several copepod body lengths across the flask.

\section{Radiotracer experiments}

Radiotracer experiments gave results similar to those of the ZIA experiments. Two experiments were carried out with water samples dominated by Phaeocystis pouchetii. In the first experiment (Stn 2 in the ZIA experiments), where the $P$. pouchetii colonies were in 

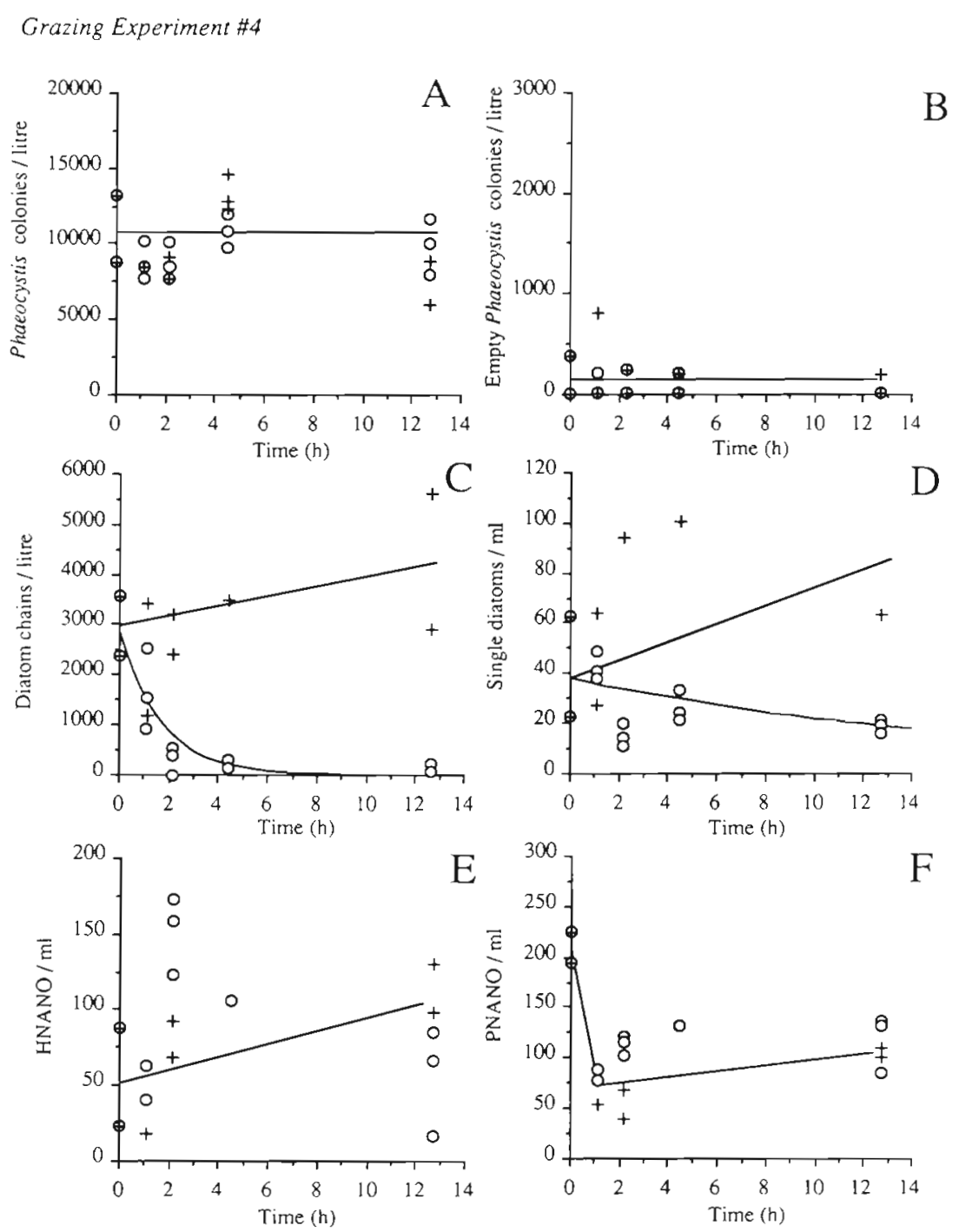

Fig. 8. ZIA Expt 4. Predation of Calanus finmarchicus upon natural algal populations. Healthy Phaeocystis pouchetii colonies were not subject to predation (A) and the number of empty colonies did not change during the course of the experiment (B). Chainforming diatoms (C) and single diatoms (D) were efficiently consumed, while no significant trend can be seen for Hnano (E) and Hnano (F). Symbols as in Fig. 2

where they were in poor condition. This discrepancy may be due a variety of factors, including turbulence, light, nutrients and competition from other protist species.

It has been suggested that large size in Phaeocystis pouchetii colonies may have an inhibitory effect on predation by copepods, at least for colonies in the range 500 to $1000 \mu \mathrm{m}$ in diameter (Schnack 1983, Huntley et al. 1987). The selective predation described in this experiment cannot be related to colony size, as colonies from the 5 stations were not significantly different in equivalent circular diameter (means ranged from 451 to $581 \mu \mathrm{m}$ and standard deviations from 20 to 126 ). Nor can the results be explained by budding of $P$. pouchetii into smaller colonies, as the number of colonies, number of cells and area of the colonial matrix all decreased, or by the liberation of $P$. pouchetir cells into the flagellated form, as the number of free Pnano did not increase significantly.

Expt 3 is important in the demonstration of unpalatability, as it showed no predation upon Phaeocystis pouchetii for the first $10 \mathrm{~h}$, but active predation in the $22 \mathrm{~h}$ sample. Copepods are known to be most active in predation at the onset of experiments, with a reduction. in predation rate of as much as $90 \%$ after $12 \mathrm{~h} \mathrm{(McAl-}$ lister 1970, Dagg \& Grill 1980). In contrast to the pat- 
Fig. 9. ZIA Expt 5. Predation of Calanus finmarchicus upon natural algal populations. Healthy Phaeocystis pouchetii colonies were not subject to predation by $C$. finmarchicus (A), C. hyperboreus (B) or C. glacialis (C). Symbols are: $(+)$ control; $(0)$ C. finmarchicus; (ه) C. hyperboreus; (D) Metridia sp.
Grazing Experiment \#5
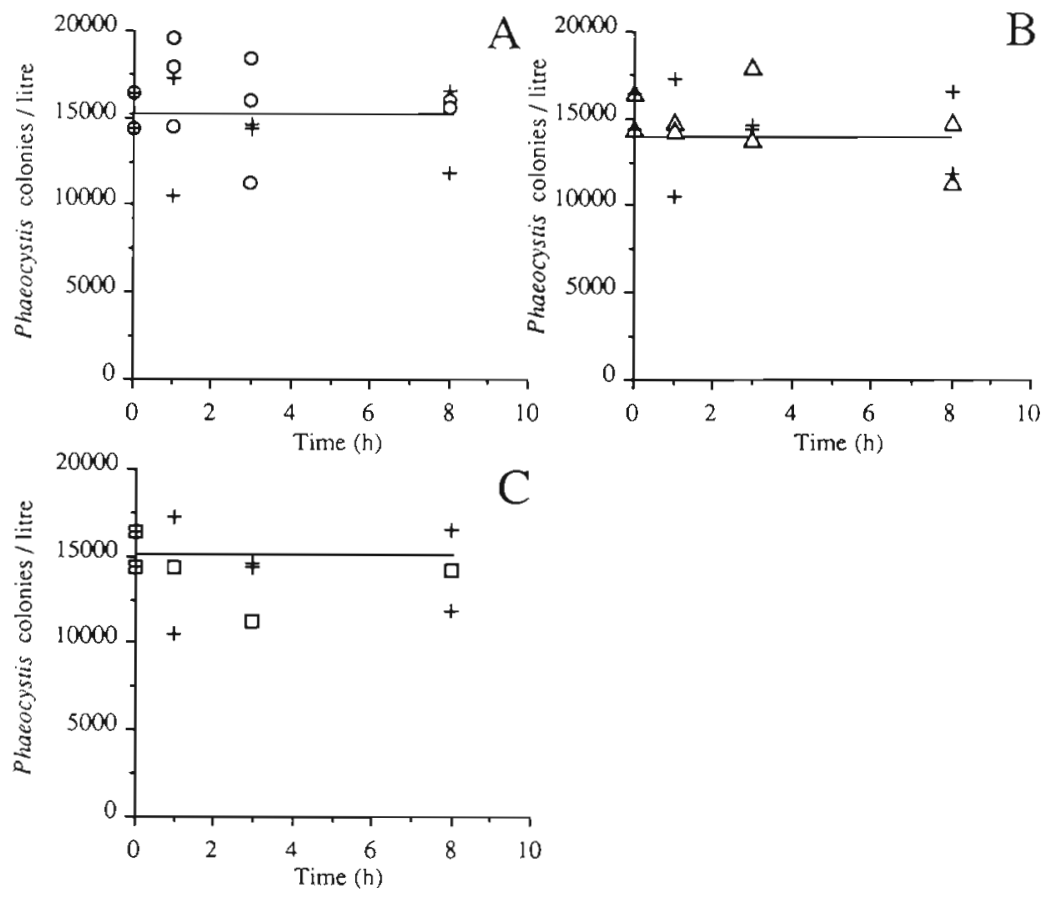

B tern for predation upon $P$. pouchetii from Stns 1, 2 and 3 , predation upon diatoms was high in all experiments beginning with the first sampling period.

Small differences in feeding preference for single plankton species, if maintained over several weeks, have a large impact on species composition of natural phytoplankton communities (Riley et al. 1949, Margalef 1958, Uye \& Takamatsu 1990). Thus the unpalata- bility of Phaeocystis pouchetii colonies would have a strong impact on the development and species composition of algal blooms in the Barents Sea. For successful competition with other algal species, the ability to avoid copepod predation has an obviously beneficial effect, and differential grazing by copepods upon diatoms and $P$. pouchetii has been proposed as an important factor in determining Arctic phytoplankton

Table 4. Calanus spp. Results of radiotracer experiments: clearance rates ( $\pm \mathrm{SD}$ ) for predation experiments with natural samples of algal prey. N: no. of predators

\begin{tabular}{|c|c|c|c|c|}
\hline Expt & $\begin{array}{l}\text { Predator spp. } \\
\text { (Stage) }\end{array}$ & $N$ & $\begin{array}{l}\text { Time } \\
(\min )\end{array}$ & 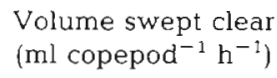 \\
\hline 2 & C. finmarchicus (CIV) & 17 & 20 & $7.6 \pm 2.4$ \\
\hline 2 & C. finmarchicus (CV) & 27 & 20 & $5.3 \pm 1.0$ \\
\hline 2 & C. finmarchicus (CVI-female) & 16 & 20 & $12.4 \pm 4.7$ \\
\hline 2 & C. finmarchicus (CVI-male) & 1 & 20 & $0.3^{\mathrm{a}}$ \\
\hline 2 & C. glacialis (CIII) & 53 & 21 & $3.5 \pm 1.4$ \\
\hline 2 & C. glacialis (CIV) & 33 & 21 & $4.2 \pm 3.0$ \\
\hline 2 & C. glacialis (CV) & 4 & 31 & 10.0 \\
\hline 5 & C. finmarchicus (CIV) & 7 & 23 & 0 \\
\hline 5 & C. finmarchicus (CV) & 12 & 23 & $0.3 \pm 0.1$ \\
\hline 5 & C. finmarchicus (CVI-female) & 13 & 23 & $0.2 \pm 0.1$ \\
\hline 5 & C. finmarchicus (CVI-male) & 1 & 67 & $0^{\mathrm{a}}$ \\
\hline 5 & C. glacialis (CIII) & 2 & 43 & 0.1 \\
\hline 5 & C. glacialis (CIV) & 45 & 23 & 0 \\
\hline 5 & C. glacialis (CV) & 137 & 23 & $0.1 \pm 0.1$ \\
\hline 5 & C. glacialis (CVI-female) & 17 & $23-58$ & 0 \\
\hline
\end{tabular}




\section{Relative Size of Predator \& Prey Species}

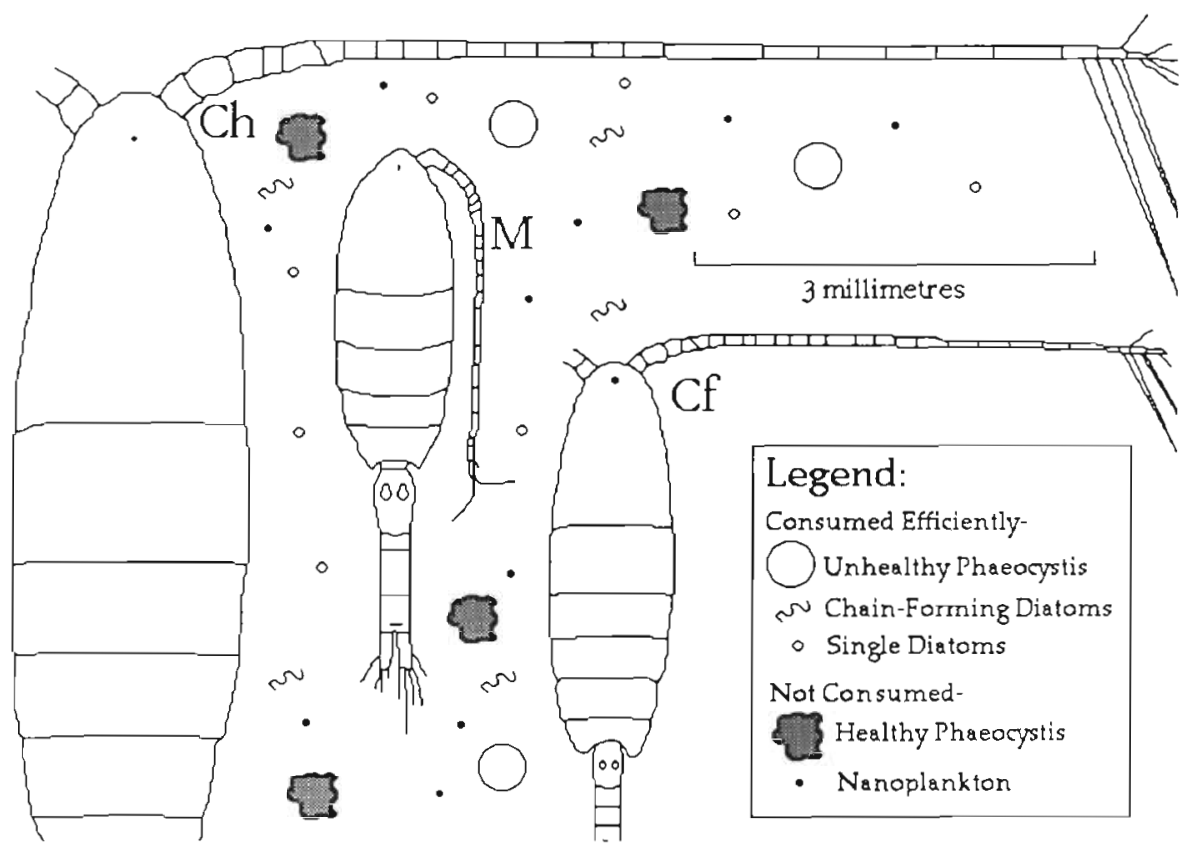

Fig. 10. Relative size of predator and prey species, combining species found in all 5 predation experiments. Legend lists prey species according to their susceptibility to predation, with susceptible cells listed in decreasing order according to measured predation rates. Cf: Calanus finmarchicus; Ch. Calanus hyperboreus; M: Metridia longa species composition (Goering \& Iverson 1981, Skjoldal \& Rey 1989). In addition, the rapid rates at which palatable $P$. pouchetii are consumed suggests a rapid transfer of colonial material to secondary production at the collapse of the bloom.

Examination of the relative sizes of predators and prey utilized in this study suggests that Phaeocystis pouchetii at the concentrations present in the experiment represent large, easily captured parcels of food (Fig. 10), and the results showing very high predation rates on the colonies should not be surprising. We believe, therefore, that without the anti-predation ability demonstrated in this study, $P$. pouchetii would have severe difficulty maintaining itself for prolonged periods as a bloom species.

One aspect of predation upon Phaeocystis pouchetii blooms that was not examined in this study is the effect of protistan predators upon the colonies. Admiraal \& Venekamp (1986) have found significant predation by tintinnids during a bloom off the coast of Holland. Tintinnids apparently have the ability to remove single $P$. pouchetii cells at a rapid rate and also, but with less efficiency, to sweep the surface of the colonies, removing cells. Tintinnids were abundant during this study, but were unfortunately not enumerated or studied.

It seems clear that the phenomenon of unpalatability goes far in explaining the dominance of Phaeocystis pouchetii in the Barents Sea, and probably in other environments, if other $P$. pouchetii populations share this property. The system appears to be similar to the defenses evolved by seaweeds and land plants to pre- vent predation. In these organisms, long-lived tissues are protected by anti-herbivore and anti-digestion compounds (Rhoades \& Cates 1976. Hay \& Fenical 1988)

Avoidance of predation by Phaeocystis pouchetii is probably a result of the production of an extracellular (or slime-embedded) compound, as the adverse effects associated with this species have only been reported for the colonial form. $P$. pouchetii cells contain chrysolaminarin vesicles that are extruded through the plasmalemma. Upon contact with seawater, they solidify into the mucilaginous envelope that forms the colony (Chang 1984). The same process also occurs in Prymnesium parvum, but in this case the vesicles do not solidify (Carter 1937). This process provides an excellent mechanism for the release of anti-predation and anti-microbial substances in the former and toxin in the latter. Indeed, the extracellular release by $P$. pouchetii into the surrounding mucilaginous envelope is complex, with $32 \%$ of total carbon fixed during the day secreted into the colonial matrix as largemolecular-weight compounds, and reprocessing occurring during the night to smaller molecules (Veldhuis \& Admiraal 1985, Lancelot et al. 1987). Behaviour observed for Calanus finmarchicus with $P$. pouchetii colonies are similar to results obtained by Huntley et al. (1986), DeMott (1989) and Claustre et al. (1990), showing rejection of toxic and low-quality food.

Of the possible anti-predation compounds, acrylic acid and dimethylsulphide (DMS) should be considered as prime candidates. The former compound 
would make consumption of Phaeocystis pouchetii akin to eating hot plastic, while the latter is related to the alkyl sulphides of the onion and garlic family. $P$. pouchetii is well known for its production of acrylic acid, and the prymnesiophytes are second only to the dinoflagellates in production of DMS, with natural assemblages of colonial $P$. pouchetii producing much greater quantities than cultures dominated by unicells (Barnard et al. 1984, Keller et al. 1989, Gibson et al. 1990).

It is important to note here that predation upon Phaeocystis pouchetii is probably not as simple as 'sick colonies are eaten'. Results from culture experiments where $P$. pouchetii served as excellent prey (Huntley et al. 1987, Tande \& Båmstedt 1987) suggest that, as usual, the behaviour and, therefore, the production of extracellular compounds by protists is complex (Estep \& MacIntyre 1989a). Although these cultures were not 'sick' they were clearly not producing anti-predation compounds either. Thus we can reconcile data from the Antarctic showing no predation upon $P$. pouchetii (Schnack et al. 1985) with data from the Arctic showing active predation (Eilertsen et al. 1989), although in the latter case, the results should be interpreted with caution, as they are based on gut fluorescence experiments in mixed diatom/Phaeocystis populations - a situation complicated by the much higher fluorescence of diatoms as compared with $P$. pouchetii.

It appears that the 'legend' of the unpalatability of Phaeocystis pouchetii began, as do most good legends, with a strong foundation in fact. Future studies are needed to determine the compound responsible for the antipredation effect of $P$. pouchetii colonies. Visual observations on prey populations, including protistan predators, should be encouraged, as these give more information on the exact behaviour of the predator species involved, and measure all consumed material, regardless of its autofluorescence or propensity to adsorb radioactive labels. Image analysis has proven to be an excellent tool for the rapid estimation of predation effects. It also avoids errors in distinguishing between live and dead material, which are a problem with 'blind' methods like the Coulter Counter. By using ZlA we were able to collect and analyse all data for each experiment before beginning the next, allowing us to plan each part of the experiment efficiently during a 2 wk cruise.

\section{SUMMARY}

(1) Arctic copepods show highly selective predation on in situ phytoplankton communities, with chainforming diatoms as the preferred food. Predation was selective for longer diatom chains.
(2) Predation upon Phaeocystis pouchetii colonies is a function of the physiological state of the colonies. Healthy colonies are not consumed, possibly as a result of the production of anti-predation compound(s) Unhealthy colonies are consumed by zooplankton at rates higher than those for co-occurring diatom species.

(3) The ability of Phaeocystis pouchetii colonies to avoid predation by copepods has strong implications for differential predation pressure and thus species composition for Arctic food-webs.

(4) Predation upon heterotrophic nanoplankton, autotrophic nanoplankton and cyanobacteria was not detected by the methods used in these experiments.

(5) Future predation studies should include examinations of both chemical and behavioural aspects of protistan prey.

Attributes and acknowledgements. Nejstgaard and Estep performed the microscopic experiments and the image analysis of the samples, Nejstgaard, Rey and Skjoldal performed the radiotracer studies. We thank A. Hassel, W. Melle, L. Omli, F. Macintyre, Draugen and the crew of the RV 'G.O. Sars' for their assistance. This work was partially supported by grants from the Norwegian Technical and Industrial Research Council and the Norwegian Council for Fisheries Research. This work is dedicated to Prof. J. McN. Sieburth, who began his cares in marine microbiology with a study on the bacterial sterility of penguin guts and Phaeocystis pouchetii and under whom the first author was trained as a marine microbiologist.

\section{LITERATURE CITED}

Admiraal, W., Venekamp, L. A. H. (1986). Significance of tintinnid grazing during blooms of Phaeocystis pouchetii (Haptophyceae) in Dutch coastal waters. Neth. J. Sea Res. 20: $61-66$

Barnard, W. R., Andreae, M. O., Iverson, R. L. (1984). Dimethylsulfide and Phaeocystis pouchetii in the southeastern Bering Sea. Contin. Shelf Res. 3: 103-113

Bradstock, M. Mackenzie, L. (1981). The Tasman Bay slime story. Catch 8: 29-30

Burkholder, P. R. Sieburth, J. MCN. (1961). Phytoplankton and chlorophyll in the Gerlache and Bransfield straits of Antarctica. Limnol. Oceanogr. 6: 45-52

Båmstedt, U., Tande, K. (1988). Physiological responses of Calanus finmarchicus and Metridia longa (Copepoda: Calanoida) during the winter-spring transition. Mar. Biol. 99: 31-38

Carmichael, W. W. (1986). Algal toxins. Adv. Bot. Res. 12: $45-101$

Carter, N. (1937). New or interesting algae from brackish water Arch. Protistenk. 90: 1-68

Chang, F. H. (1984). The ultrastructure of Phaeocystis pouchetii (Prymnesiophyceae) vegetative colonies with special reference to the production of new mucilaginous envelope. N. Z. Jl mar. Freshwat. Res. 18: 303-308

Claustre, H., Poulet, S. A., Williams, R., Marty, J.-C., Coombs, S., Ben Mlih, F., Hapette, A. M., Martin-Jezequel, V (1990). A biochemical investigation of a Phaeocystis sp. bloom in the Irish Sea. J. mar. biol. Ass. U.K. 70: 197-207

Dagg, M. J., Grill, D. W (1980). Natural feeding rates of 
Centropages typicus females in the New York Bight. Limnol. Oceanogr 25: 597-609

Daro, M. H. (1985). Field study of selectivity, efficiency, and daily variation in the feeding of the marine copepod Temora longicornis, in the Southern Bight of the North Sea. Bull. mar Sci. 37: 764

DeMott, W. R. (1989). Optimal foraging theory as a predictor of chemically mediated food selection by suspension-feeding copepods. Limnol. Oceanogr 34: 140-154

Eilertsen, H. C., Tande, K. S., Taasen, J. P. (1989). Vertical distributions of primary production and grazing by Calanus glacialis Jaschnov and C. hyperboreus Kroyer in Arctic Waters (Barents Sea). Polar Biol. 9: 253-260

Estep, K. W., MacIntyre, F. (1989a). Taxonomy, tife cycle, distribution and dasmotrophy of Chrysochromulina: a theory accounting for scales, haptonema, muciferous bodies and toxicity. Mar Ecol. Prog. Ser. 57: 11-21

Estep, K. W., MacIntyre, F. (1989b). Counting, sizing and identification of algae using image analysis. Sarsia 74: $261-268$

Frost, B. W. (1972). Effects of size and concentration of food particles on the feeding behavior of the marine planktonic copepod Calanus pacificus. Limnol. Oceanogr. 17 805-815

Gibson, J. A. E., Garrick, R. C., Burton, H. R., McTaggart, A. R. (1990). Dimethylsulfide and the alga Phaeocystis pouchetii in Antarctic coastal waters. Mar. Biol. 104: 339-346

Goering, J. J., Iverson, R. L. (1981). Phytoplankton distribution in the southeastern Bering Sea shelf. In. Hood, D. W., Calder, J. A. (eds.) The eastern Bering Sea shelf: oceanography and resources. Univ. Wash. Press, Seattle, p. 933-946

Haq, S. M. (1967). Nutritional physiology of Metridia lucens and $M$. longa from the Gulf of Maine. Limnol. Oceanogr. 12: $40-51$

Hay, M. E., Fenical, W. (1988). Marine plant-herbivore interactions: the ecology of chemical defense. A. Rev. Ecol. Syst. 19: 111-145

Huntley, M., Sykes, P., Rohan, S., Marin, V. (1986). Chemically-mediated rejection of dinoflagellate prey by the copepods Calanus pacificus and Paracalanus parvus: mechanism, occurrence and significance. Mar. Ecol. Prog Ser. 28: 105-120

Huntley, M., Tande, K. S., Eilertsen, H. C. (1987). On the trophic fate of Phaeocystis pouchetii. II. Grazing rates of Calanus hyperboreus feeding on diatoms and different size categories of $P$. pouchetii. J. exp. mar Biol. Ecol. 110: $197-212$

Kayser, H. (1970). Experimental-ecological investigations on Phaeocystis pouchetii (Haptophyceae); cultivation and waste water test. Helgoländer wiss. Meeresunters. 20: 218-233

Keller, M. D., Bellows, W K., Guillard, R. R. L. (1989). Dimethylsulfide production in marine phytoplankton. In: Saltzman, E. S., Cooper, N. J. (eds.). Biogenic sulfur in the environment. Am. Chem. Soc., p. 168-182

Lancelot, C., Billen, G., Sorunia, A., Weisse, I., Colijin, F. Feldhuis, M. J W., Davies, A., Wassman, P. (1987) Phaeocystis blooms and nutrient enrichment in the continental coastal zones of the North Sea. Ambio 16: 38-46

Mackas, D. L., Burns, K. E. (1986). Poststarvation feeding and swimming activity in Calanus pacificus and Metridia pacifica. Limnol. Oceanogr 3: 383-392

Margalef, R. (1958). Temporal succession and spatial heterogenity in plankton. In: Buzzati-Traverso, A. A. (ed.) Perspectives in marine biology. Univ. Calif. Press, Berkeley, p. $323-349$
Martens, P. (1980). Beiträge zum Mesozooplankton des Nordsylter Wattenmeeres. Helgoländer Meeresunters, 34 $41-53$

Martens, P. (1981). On the Acartia species in the northern Wadden Sea off Sylt. Kieler Meeresforsch., Sonderh. 5 153-163

McAllister, C. D. (1970). Zooplankton rations, phytoplankton mortality and the estimation of marine production. In: Steele, J. H. (ed.) Marine food chains, Oliver \& Boyd, Edinburgh, p. 419-457

Mullin, M. (1963). Some factors affecting the feeding of marine copepods of the genus Calanus. Limnol. Oceanogr. 8: $239-250$

O'Brien, W. J. (1988). The effect of container size on the feeding rate of Heterocope septentrionalis, a freshwater predaceous copepod. J. Plankton Res. 10: 313-317

Omori, M., Ikeda, T. (1984). Methods in marine zooplankton ecology. John Wiley \& Sons, New York

Peruyeva, Y. E. G. (1982). Feeding habits and food relationships between male and female stage $V$ copepodites of Metridia longa Lubbock from the White Sea. Oceanology 22: $471-476$

Rey, F., Skjoldal, H. R., Slagstad, D. (1987). Primary production in relation to climatic changes in the Barents Sea. In: Loeng, $H$. (ed.) The effect of oceanographic conditions on distribution and population dynamics of commercial fish stocks in the Barents Sea. Proc. 3rd Soviet-Norwegian Symposium, Inst. Marine Research, Bergen, p. 29-46

Rhoades, D. F., Cates, R. G. (1976). Toward a general theory of plant antiherbivore chemistry. Recent Adv. Phytochem 10: $168-213$

Riley, G. A., Tommel, H., Bumpus, D. F. (1949). Inhibitory effects of phytoplankton upon the feeding of Daphnia magna with reference to growth, reproduction, and survival. Ecology 12: 1-168

Sakshaug, E., Skjoldal, H. R. (1989). Life at the ice edge. Ambio 18: 60-67

Savage, R. E. (1930). The influence of Phaeocystis on the migration of herring. Fishery Invest., Lond. (Ser. II) 12: 5-14

Schnack, S. B. (1983). On the feeding of copepods in Thalassiosira partheneia from the Northwest African upwelling area. Mar. Ecol. Prog. Ser, 11: 49-53

Schnack, S. B., Smetacek, V., Bodungen, B. von, Stegmann, P. (1985). Utilization of phytoplankton by copepods in Antarctic waters during spring. In: Gray, J. S., Christiansen, M. E. (eds) Marine biology of polar regions and effects of stress on marine organisms. Wiley, London, p. $65-81$

Shilo, M. (1967). Eormation and mode of algal toxins. Bact. Rev. 31. 180-193

Sieburth, J. MCN. (1958). Antarctic microbiology. A study of Antarctic birds conducted during the 1957-58 Argentine Antarctic Expedition. Am. Inst. Biol. Sci. Bull. 8: 10-12

Sieburth, J. McN. (1960). Acrylic acid, an 'antibiotic' princuple in Phaeocystis blooms in Antarctic waters. Science 132: $676-677$

Sieburth, J. McN. (1961). Antibiotic properties of acrylic acid, a factor in the gastrointenstinal antibiosis of polar marine animals. J. Bacteriol. 82: 72-79

Sieburth, J. McN. (1965). Microbiology of Antarctica. In: Oye, P. van, Mieghem, J. van (eds.) Biogeography and ecology in Antarctica. Vol. 15 Monographiae Biolobicae. W. Junk, Den Hauge, p. 267-295

Skjoldal, H. R., Rey, F. (1989). Pelagic production and variability of the Barents Sea ecosystem. In: Sherman, K. Alexander, L. M. (eds.) Biomass and geography of large marine 
ecosystems. Westview Press, Boulder, Colorado, p. $243-288$

Skjoldal, H. R, Hassel, A., Rey, F., Loeng, H. (1987). Spring phytoplankton development and zooplankton reproduction in the central Barents Sea in the period 1979-1984. In: Loeng. $H$. (ed.) The effect of oceanographic conditions on distribution and population dynamics of commercial fish stocks in the Barents Sea. Proc. 3rd Soviet-Norwegian Symposium, Inst. Marine Research, Bergen, p. 59-89

Tackx, M., Polk, P. (1986). Effect of incubation time and concentration of animals in grazing experiment using a narrow size range of particles. Syllogeus 58: 604-609

Tande, K. S., Bamstedt, U. (1985). Grazing rates of the copepods Calanus glacialis and C. finmarchicus in arctic waters of the Barents Sea. Mar. Biol. 87: 251-258

Tande, K. S., Båmstedt, U. (1987). On the trophic fate of Phaeocystis pouchetii. I. Copepod feeding rates on solitary cells and colonies of $P$. pouchetii. Sarsia 72: 313-320

This article was submitted to the editor
Tsuji, T., Yanagita, T (1981). Improved fluorescent microscopy for measuring the standing stock of phytoplankton including fragile components. Mar Biol. 64-207-211

Uye, S., Takamatsu, K. (1990). Feeding interactions between planktonic copepods and red-tide flagellates from Japanese coastal waters. Mar Ecol. Prog. Ser. 59: 97-107

Veldhuis, M. J. M., Admiraal, W. (1985). Transfer of photosynthetic products in gelatinous colonies of Phaeocystis pouchetii (Haptophyceae) and its effect on measurement of excretion rate. Mar Ecol. Prog. Ser. 26: 301-304

Verity, P. G. , Smayda, T J. (1989). Nutritional value of Phaeocystis pouchetii (Prymnesiophyceae) and other phytoplankton for Acartia spp. (Copepoda): ingestion, egg production, and growth of nauplii. Mar. Biol. 100: 161-171

Verity, P. G., Villareal, T. A., Smayda, T. J. (1988). Ecological investigations of blooms of colonial Phaeocystis pouchetii. II. The role of life-cycle phenomena in bloom termination. J. Plankton Res. 10: 749-766

Manuscript first received: December 5, 1989 Revised version accepted: July 13, 1990 